\title{
THE IMPORTANCE AND ROLES OF LINGUISTICS IN ISLAMIC STUDIES (INTEGRATION OF LINGUISTICS WITH RELIGIOUS STUDIES)
}

\author{
Saifuddin Ahmad Husin • \\ Institut Agama Islam Negeri Antasari Jl. A. Yani km. 4.5 Banjarmasin \\ e-mail: saifuddin@iain-antasari.ac.id
}

\begin{abstract}
Knowledge integration has been studied as the process of incorporating new information into a body of existing knowledge with an interdisciplinary approach. Language is not only the object of scientific study of linguistics, but also the object of study of other related disciplines. The importance of language in many studies and disciplines of knowledge has led to its status as a condition sin qua non to true understanding of other scientific objects of disciplines of knowledge. The mastery of Arabic language for example is a must for the study of Islamic religious texts. The religion of Islam places language on a very high position that it is explicitly mentioned in the Qur'an as one of the signs of the existence of God.
\end{abstract}

\begin{abstract}
Abstrak
Integrasi pengetahuan telah dipelajari sebagai proses menggabungkan informasi baru ke dalam bentuk pengetahuan yang ada dengan pendekatan interdisipliner. Bahasa tidak hanya objek studi ilmiah linguistik , tetapi juga objek studi yang terkait dengan disiplin dan lainnya . Pentingnya bahasa dalam banyaknya pembelajaran dan disiplin ilmu pengetahuan telah menyebabkan statusnya sebagai syarat sin qua non untuk pemahaman yang benar tentang benda-benda ilmiah lainnya dari disiplin ilmu pengetahuan. Penguasaan bahasa Arab misalnya adalah suatu keharusan untuk belajar teks-teks agama Islam. Agama Islam menempatkan bahasa pada posisi yang sangat tinggi yang secara jelast disebutkan dalam Al-Qur'an sebagai salah satu tanda-tanda keberadaan Allah
\end{abstract}

Kata Kunci : Knowledge integration, Linguistics, language, Islam, Shari'ah.

Lecturer of Linguistics and Cross-Cultural Understanding, Tarbiyah Faculty, Antasari State Institute for Islamic Studies, Banjarmasin - Indonesia. 


\section{A. INTRODUCTION}

The history of language can be said as old as human history. Following stages of how society evolves, language was once under religious (theological) influences. Linguistics has been struggling under strangehold of religious beliefs, especially superstition, and ethnocentrism for centuries. The role and nature of human languages was perceived through the world views preached by various religions. There have been claims for the divine origins of certain languages, conferring special status on their speakers. Greeks, for example, believed that their language was superior to all other languages. It was the language spoken the Olympian gods. Theirs was the only language with regularity, rules, and meaning; all other languages were arbitrary and meaningless (barbaroi) whence the modern English word "barbarian.” (Syeed, 1984: 541).

In India, Sanskrit was believed to be the language of gods and worthy to be studied and used by the high caste of Brahmans only. The low-case Hindus could not listen to the Sanskrit verses from the holy scriptures, and severe punishments were prescribed for such sacrilegious acts.

In Judeo-Christian world, too, similar unscientific views persisted until recently. Hebrew was God's own language, the language spoken in the heavens, the first language spoken on the earth and therefore the mother of all languages in the world. Wonderly and Nida, discussing the impact of early Christian beliefs on linguistics, admit that "one of the factors which retarded linguistic progress was the belief among early Christian writers, and persisting well into the Renaissance era, that all languages were derived from Hebrew. ${ }^{1}$

However, this is not the case in Islam. All Muslims are obliged to pursue knowledge, and encouraged to use their reasoning. A well-rounded or knowledgeable person is more preferred in the sight of God than an ignorant, because knowledgeable person has the potential to know and think of ominpresence and omnipotent nature of God. One of the signs of God's existence is the creation of languages or language variation. Therefore, language and linguistics, the study of languages, has an important role in Islam and Islamic studies. Its importance is not of ethnocentrism nor religious superstition as the case of the above mentioned languages, rather it is one of a pre-requisite or conditio sin qua non of Islamic religious studies. Arkoun, a Muslim sociologist, when discussing a true understanding of Islam and Islamic teachings include linguistic analysis as one of integral parts, saying:

....unthought as the power employed by the traditional ulama and ideological Islamic states in order to guarantee that a deeply dogmatic and unapproachable version of Islam is protected from all intellectual and scientific analysis. Arkoun uses unthought to refer to "an Islam that is isolated from the most elementary historical reasoning, linguistic analysis or anthropological decoding” (Arkoun, 2002: 308).

\footnotetext{
${ }^{1}$ See William Wonderly and Eugene Nida, "Linguistics and Christian Mission," Anthropological Linguistics, 5:104-44.
} 
The above quotation from Muhammad Arkoun's The Unthought in Contemporary Islamic Thought ${ }^{2}$ supports the view that linguistics is one of the key elements in the understanding of Islam

Linguistics is a scientific study of language. Yet the study of language is not the monopoly of linguistics alone. Other disciplines of knowledge such as psychology, communication science, sociology, and anthropology also study language. Historically, linguistics can be said as a science which developed from the needs of anthropologists to better understand a community which becomes subject of their study. In order to achieve their objectives, the anthropologists equipped themselves with mastery of the language of the community. If we pay a closer attention at the birth of anthropology as a science, we can trace it back to Western, initially European and later American, activities of Christian missionaries. In their attempts to win people's heart or sympathy their approach was to use the vernacular of the community. From the records of study of exotic vernaculars interests in language study flourished.

Discussing potential roles of linguistics in Islamic studies does not mean discussing linguistics, whose birth was from missionary tradition, vis-à-vis activities of Islamic studies. This article is aimed to survey some Islamic religious basis for the study and importance of language and linguistics as well as to explain that comprehensive and correct understanding of a language, in this case Arabic, is very crucial in understanding many aspects of Islamic studies. In the discussion, the role and function of language as well as the relationship of language and some branches of Islamic studies will be dealt.

\section{B. ARABIC AS THE LANGUAGE OF THE REVELATION}

The general principle for the selection of a language for divine revelation seems to be the adoption of the language of the people for whom the message is intended. Arabic is one such language chosen according to this eternal divine principle. It was chosen as a medium of the last divine message because it happened to be the mother-tongue of the last messenger of Islam and of the language community chosen to establish the word of God on earth under the immediate leadership of the Prophet. The words 'Arabi and 'Arabiyyan occur eleven times in the Qur'an. This is only to emphasize the fact that the message of Allah had been revealed in other languages in earlier times, whereas the Qur'an was revealed in Arabic, the language of the people who were the immediate addresses of the message.

In earlier times when language variation and geographical barriers were insurmountable, prophets would be sent to particular linguistic groups, and their role was limited to their particular regions or language communities. But the function of Islam as the final and universal message is to unite all linguistic communities, all nations, and all races. Arabic was the language selected to perform the role of an international Islamic language, the medium of the last divine message addressed to all of mankind:

\footnotetext{
${ }^{2}$ Arkoun, Mohammad. 2002. The Unthought in Contemporary Islamic Thought London: Saqi Books
} 


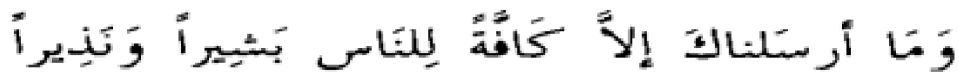

"We have not sent you out but as a messenger of good tidings and a warner unto all mankind"

Ninety percent of the world's Muslims do not speak Arabic as their native language. Yet in daily prayers, when reading the Qur'an, or even in simple conversations with each other, Arabic rolls off any Muslim's tongue readily. It may be broken or heavily accented, but most Muslims make the attempt to speak and understand at least some Arabic.

Arabic is so important to understanding the faith of Islam because regardless of their linguistic, cultural, and racial differences, Muslims form one community of believers. This community is based on their shared faith in One Almighty God, and the guidance He has sent down to mankind. His final revelation to mankind, the Qur'an, was sent over 1400 years ago in the Arabic language. Arabic thus serves as a common language among this diverse community of believers.

The original Arabic text of the Qur'an has been preserved from the time of its revelation. Translations have been done into various languages, but they all refer back to the original Arabic. In order to fully understand the magnificent words of their Lord, Muslims make every attempt to understand the rich and poetic classical Arabic language.

Since understanding Arabic is so important, most Muslims try to learn at least the basics. Many pursue further study to understand the full text of the Qur'an in its original.

\section{HUMAN INNATE SPEECH FACULTY AS A DIVINE GIFT}

Linguistics, as a scientific study of human languages, studies language as an innate faculty shared by all humans. Human speech faculty is what sets them apart from the rest of other members of the great animal kingdom. Arabic philosophy dictates al-insanu bayawan al-natiq, human is the talking animal. In other words, the faculty of speech is both species-specific and species-uniform to all humans. The Qur'an refers this in Sura $55: 1-4$ :

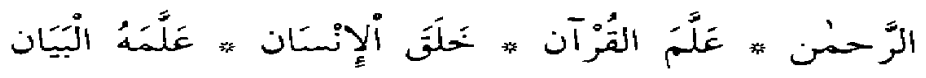

The Beneficent (God) taught the Qur'an. He created man, taught him the mode of speech.

It is clear from this verse that God created man with the faculty of speech, not with Greek, Hebrew, or Arabic speech. It is not a particular language, but a capacity to learn any particular human language that is innate to human beings. It is possible that any language might have been a vehicle of God's message sometime in the history of the speakers of that language. Had God sent His message in a language not spoken by the people of the target message, His message would have been comprehensible by the people. This is so clear in the Qur'an (14:4):

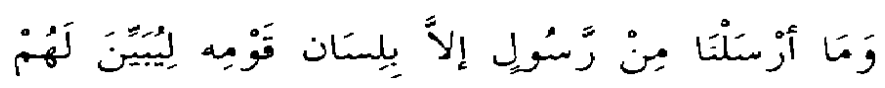


And We have not sent any messenger except with the language of the people, in order that he might make (things) clear to them.

\section{LANGUAGE DIVERSITY AND ISLAM}

The growth and diversification of languages and change in their phonetic, phonological, and syntactic rules is an important field of inquiry. Synchronic and diachronic linguistics, comparative study of different languages, and changes in language provide an important study of one of the signs of the existence of God. The Holy Qur'an invites Muslims in particular and all mankind in general to study and respect the diversity of languages and declares it an important sign of divine power at work in the organization of the universe. The text of the particular verse in which the variation of language is mentioned reads:

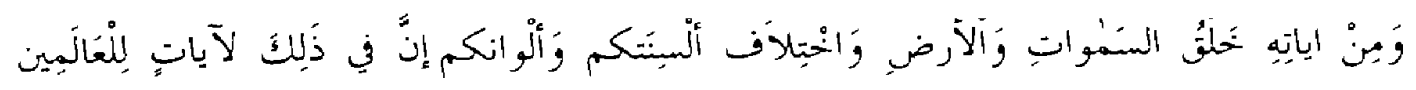

And among His signs is the creation of the heavens, and the earth, and variation in your languages and your colors, verily in that are signs for those who know (Qur'an 30:22).

Thus a scientific study of language variation is as important as the study of the creation of the earth and the heavens. In the variation of languages lies God's signs, and those who attempt to know them are designated by the Qur'an 'alimun, an honorable title conferred by God on linguists who are motivated by this world view.

The variation among languages can be described by definite rules. They vary so systematically and with such regularity that linguists have compare these rules to the "sound laws" of physics. Every time we study a new language, analyze its grammar, and compare its new forms with its old ones or other related dialects and languages, we marvel at the perfect design in its structure, and should therefore exclaim: so blessed be Allah the best creator (fatabarakallabu absanul khaliqin).

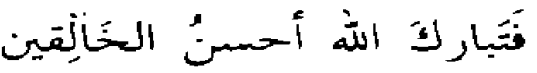

\section{E. LANGUAGE AS A VEHICLE OF KNOWLEDGE}

Ibn Khaldun (p. 277) considers language as a means to acquire and impart knowledge. Anyone who studies a discipline of knowledge or science infers and concludes ideas from the words that used to express those ideas. In order to do this one must have knowledge of linguistic meaning of these words. This knowledge is only possible if he or she is familiar with the language he or she uses. Ibn Khaldun (p. 308) also postulates that one of the most fundamental properties is its power to predict events. The function of thought is to create a model of reality by means of internal symbolism. In its process of creating a model of reality human mind translates external objects or events into symbols and therefore enables the mind to produce further symbols by inferential reasoning. Finally the mind makes hypothesis or calculation of these new symbols into external processes. 
According to Ibn Khaldun the relationship between perception, knowledge, and language is a process starting from perception of realities (idrak or tasamwur). Perception is then followed by affirmation or negation of the essential attributes of these realities. After affirming or negating these attributes the min then processes and establishes a scientific thought or knowledge. In order to verify, that is accepted or rejected, the body of thought or knowledge in one's mind needs to be communicated. Now here comes the role of language. The relationship of language and knowledge is that linguistic expression is no more than the interpreter of ideas of the mind. One conveys his ideas through discussion, instruction, and constant scientific research.

If we refer to Islamic studies or Shariah studies, we can instantly see that it is an application or object of Arabic Islamic linguistics. The knowledge of Arabic Islamic linguistics has a special place in Shariah studies, because the ultimate purpose to study Arabic is to study discourses of Shariah as well as extraction of rules from quotations that are conveyed originally in Arabic. Many scholars discuss the significance of knowledge and specialization of Arabic linguistic in the study of Shariah. Shatibi (114-118) concludes that there is no substitute for an expert in extraction of rules or mujtahid but he must be an expert in Arabic language up to the highest level of competence and therefore is able to judge its rules intuitively.

Arabic linguistic knowledge is a fundamental factor in understanding religious scriptures, be it Qur'anic or Hadith texts. It is also important in the process of discovering or extracting any implied or contextual meaning. The extent of one's knowledge of Shariah is measured by the extent of his knowledge of Arabic linguistics. Al-Zarkasyi (1972:114115) said that lack of complete mastery of Arabic language makes one unqualified in the business of interpretation or exegesis of Qur'anic or Hadith texts.

The relationship between linguistic and Shariah is basically interdependent in nature, because the fact that language is a reflection of belief of a language community. It is from this very belief that norms, values and world views of language speakers are derived. At the surface level, the relationship comes from the fact that Shariah discourse has almost every features and characters of a language discourse. The difference is in themes. Linguistics discusses all cultural, social and legal aspects of a discourse, Shariah focuses on rules extraction and codification as well as ways of relating texts to rules. In both relationships include belief (aqidab), values, shared local and temporal contexts, communication of all that, and texts analysis.

While two main references of Islam, Qur'an and Hadith, are delivered in Arabic language, the religion of Islam is universal in nature. Its universality is recorded in the Qur'an (34:28): We have not sent you but as a (messenger of) bless to all mankind. Therefore, the best way to understand the two is to know the convention of Arab in discourse during the period of revelation. However, this is not to say that expressing Islamic message in non-Arabic languages is not allowed in Islam. It is preferable for Muslims to stick to Arabic Islamic terminology in their discussion of Islamic topics in order to avoid influence of non-Islamic linguistic conventions. 


\section{F. LANGUAGE AS HUMAN RIGHT}

Language right is inclusive in human right in Islam. It is included in the rights of freedom, human dignity, peaceful life, good company and neighborhood, the rights of both rulers and subjects. The importance of language within the basic necessity of life also emphasizes the humanistic status of language rights.

Language rights are parts of human development. Any resistance to it will adversely affect human honor. It will also be an act of rejection to God's signs of language variation as indicated in the Qur'an (30:22): And among His signs is the creation of heavens and earth, and the variations in your languages (alsinatikum) and your colors; verily in that are signs for those who know. It is clear that human dignity cannot be accomplished without maximum opportunity to benefit from this great bounty of Allah, that is language, an art of expression.

Language is a vehicle for the religious discourse. It has always been in company of various religions as it is the case with Islam and Arabic, as well as English and Christianity in modern ages. Deficiency in linguistic competence among members of any language group is a great threat to their identity (Al-Shatibi, n.d.:28).

Ibn Taymiyah is of the opinion that teaching and learning of Arabic is a [collective] selective obligatory (fard al-kifayah) for a group of people ${ }^{3}$. It is, however, personal obligatory or a sine qua non for the study of, and for anyone who wishes to study, Islamic religious texts.

\section{G. LINGUISTICS INTEGRATES WITH ISLAMIC STUDIES}

Linguistics tradition of Arabic language studies started and grew up as practical and purposeful science. Its objective was to safeguard recitation and comprehension of the Qur'an. This objective was developed to cover not only every linguistic aspects of the Qur'an but traditions of the prophet as well. Later it developed its device, and theoretical framework and widened its scope to include all kinds of Arabic speech and texts.

Al-Attas (1991: 82) claimed that Arabic Islamic linguistics aims from its inception at achieving proper understanding of the Qur'an and serving it in all dimensions. The objectives, conditions and stages of development of Arabic linguistics are shared with other Islamic sciences. It is not therefore, unexpected that theories and issues in Arabic linguistics are related to Islamic faith ('aqidab) and general concepts of Islam which are derived from the Qur'an, Hadith and related to the nature of Arabic language. Arabic linguistics shares methodological principles with Fiqh, Usul al-Fiqh, Usul al-Din, and Hadith narration studies.

On the other hand, Shari'ah sciences influenced linguistic sciences in theoretical basis, methodological issues and in matters related to language narration, justification of rules, grammatical analogy, expansion of branch rules, etc. Influence of linguistics on Shari'ah sciences can also be found in Figh where grammar is given a wider scope to

\footnotetext{
${ }^{3}$ Ibn Taymiyah, Majmu' Fatawa, vol. 32, p.252,255, vol. 3 p.206, 29:12.
} 
cover every aspect of language structure and styles that can affect derivation or rules, codification, interpretation, and judgment.

\section{H. LINGUISTIC PRINCIPLES OF SHARIAH SCIENCES}

Shariah studies is a field of practical application of linguistic studies. Specialists in Shariah have examined the linguistic questions in its main approaches. An important point of study is comprehensive analysis of linguistic basis for the disagreement in jurisprudence and theological schools. The very particular principles of analogy (qiyas) may need to be reviewed in line with its refutation by some scholars. In addition to extracting rules evidences, linguistic principles of Shariah include codifying ways of comprehending texts in the context of conventional Arab discourse, and socio-cultural situations of its encoding. It also contains the interaction of texts with reality, and effects of linguistic change on intellectual and social developments. It is hoped that further research will help to develop linguistic principles of Shariah studies to a level that represents an integration of linguistics with other fields of knowledge.

Muhammad Shehu Abdussalam (1999:76) says that Islamic jurisprudence or Usulal-Fiqh comprises of principles of three main disciplines: Shariah injunctions, linguistics, and Islamic theology or ilm al-Kalam. Linguistic study in Shariah sciences deals with meanings of the texts, Shariah textual evidences in the Qur'an and Prophet's traditions as well as linguistic explanation of several types of meaning, such as, real (ma'nawy) and metaphor (majasy), general and specific (khas-'aam), bound and free, direct and indirect, etc. Linguistic principles of Shariah intend to employ linguistic analysis to explain Shariah purposes in the texts .

The main issue of Islamic jurisprudence is to generate Shariah injunctions that guide life of individuals and society. Such generating is guided and guaranteed by vigorous intellectual effort (ijtihad) in the understanding of texts. The analogy (qiyas) derives its importance from the fact that Shariah texts which are finite provide rules for worldly affairs that are infinite. Semantic principles are essential parts of qiyas process.

\section{LANGUAGE AND DA'WAH}

Da'wah, literally means the call or invitation, in Islamic terminology refers to a form of persuasion to change people's attitude and to conform with the injunctions of God as brought by His Prophet, Muhammad. Language plays a major role in da'wah as the easiest, quickest, and most effective form of persuasion, hence the type, the standard of language used and the style of expression matter a lot. Qur'anic excellent eloquence has attracted many into the fold of Islam. One such example has been Caliph Umar bin alKhattab who embraced Islam after listening to a brief reading from the first verses of surah Taba. Ample others were also influenced in similar ways.

Great orators are known with their ability to convince their audience, influence their decision and change their attitude to many vital issues. In recognition of this fact 
Allah ordained in the Qur'an (16:125) that one should be mindful of the expressions he uses and stick to the concept of (wise argument) while inviting people to the fold of Islam:

Invite all to the way of Thy Lord with wisdom and beautiful preaching, and argue with them in ways that are the best.

A preacher not only must have high proficiency but also the quality of being eloquent and conversant with grammatical and stylistic rules of the language in which he conveys his message to the people. All of the above qualities help the preachers' bids to persuade people to change their attitude in accordance with his da'wah (Abdussalam, 1999: 72).

Relevance of the linguistic and educational standard of the target group has great impact in either winning the people's attention or driving them away from the preacher $\left(d a^{\prime}\right)$ and his message. The standard of language is of great importance in the spread of his message, A da'i must consider that he is addressing the generality of the people, the knowledgeable and ignorant, illiterate and elite, this fact requires him to come always to a level familiar to the populace in their understanding of the written and spoken discourse, a level of simple vocabularies and plain ideas. This of course dose not negate the need to use correct, relevant and beautiful styles.

\section{J. CONCLUSION}

This article is meant to be a preliminary introduction (ta'aruf and muqaddimah) to research and studies on language and linguistics in the framework of Islamic studies. It is also meant to be first step to future research work on language studies from an Islamic perspective as embodied in Muslim heritage. Other aims of this article being that readers will have discovered how valuable and rich is Islamic heritage in the area of language and linguistics. It is also humbly hoped that readers of language and linguistics background will have understood how valuable their study undertaking in Islamic teaching perspectives.

\section{BIBLIOGRAPHY}

Abuddin Nata, Konsep Pendidikan Ibnu Sina, Disertasi pada Program Pascasarjana LAIN Syarif Hidayatullah Jakarta, 1997 (Jakarta: LAIN, 1997.)

Abdussalam, Ahmed Shehu. 1999. Islam and Language. Kuala Lumpur: Al-Hilal Publishing.

Al-Shatibi, Abu Ishaq. (n.d.). al-Muwafaqat fi Usul al-Syari'ah. Muhammad Abdullah Diraz (ed.), Beirut: Dar al-Fikr al-Arabi.

Al-Zarkasyi. (1972). Al-Burban fi 'Ulum al-Qur'an. Al-Qahirah: Isa al-Babi al_halabi. 
Arkoun, Mohammad. 2002. The Unthought in Contemporary Islamic Thought London: Saqi Books

Ibn Khaldun, Abdurrahaman. 2001. The Muqaddimah, vol 3. (Indonesian translation) Jakarta: Pustaka firdaus.

Ibn 'Taymiyah, Majmu' Fatawa, vol. 32, p.252,255, vol. 3 p.206, 29:12.

Syeed, Sayyid Muhammad. 1984. Islamization of Linguistics. Kuala Lumpur: IIT-IIU.

The Holy Qur'an 